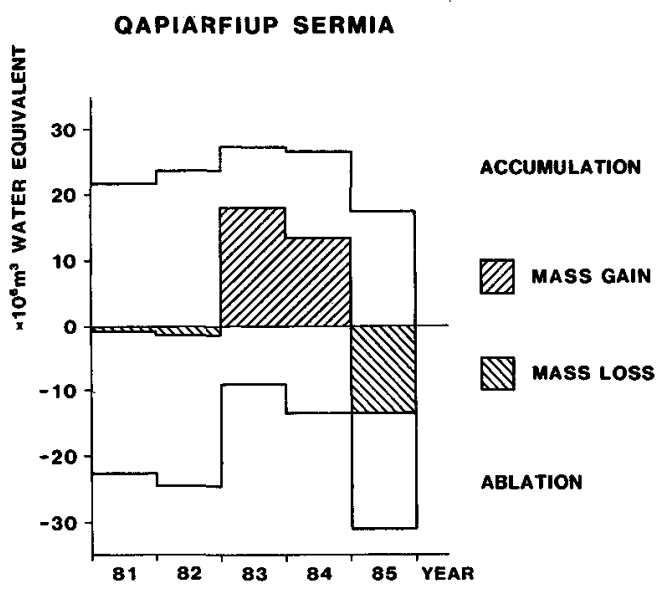

Fig. 4. Histogram of mass balance data for Qapiarfiup sermia for the years 1981 to 1985 .

\title{
References
}

Olesen, O. B. 1982: Establishment of a new survey station at Tasersiaq. Rapp. Grønlands geol. Unders. 110, 86-88.

Olesen, O. B. 1985: Glaciological investigations in 1984 at Tasersiaq and Qapiarfiup sermia, West Greenland. Rapp. Grønlands. geol. Unders. 125, 104-107.

Olesen, O. B. \& Andreasen, J. O. 1983: Glaciological, glacier-hydrological and climatological investigations around $66^{\circ} \mathrm{N}$, West Greenland. Rapp. Grønlands geol. Unders. 115, 107-111.

\section{Exceptionally high ablation in 1985 at Qamanârssûp sermia, West Greenland}

\author{
Roger J. Braithwaite
}

As part of the GGU programme of hydropower investigations in West Greenland, climatological and glaciological measurements were continued at Qamanârssûp sermia (inventory number $1 \mathrm{CH} 21002$ ) in 1985. The field programme was generally the same as in previous years (see Braithwaite, 1985a, b). The station was established in August 1979 so that records for six complete summers 1980-1985 are now available. Detailed summaries of results up to 1984 are given in Braithwaite $(1985 \mathrm{a}, \mathrm{b})$ while the latest results will be presented in a Gletscher-hydrologiske Meddelelser in spring 1986.

\section{Climatological and glaciological situation}

When the field party arrived at Qamanârssûp sermia in early June it was obvious that the 1984/85 winter had been an unusual one. There was no winter snow cover at the base camp 
Table 1. Four different ablation indices for Qamanârssûp sermia for the six years $1979 / 80$ to $1984 / 85$

\begin{tabular}{lrrrr}
\hline Year & A1 & A2 & A3 & \multicolumn{1}{c}{ A4 } \\
\hline $1979 / 80$ & 0.3 & & & \\
$1980 / 81$ & 0.4 & 0.5 & 0.5 & -0.3 \\
$1981 / 82$ & 0.4 & 0.3 & 0.4 & 0.3 \\
$1982 / 83$ & -0.4 & -0.5 & -0.5 & -0.6 \\
$1983 / 84$ & -0.4 & -0.4 & -0.4 & -0.1 \\
$1984 / 85$ & 1.1 & 0.9 & & 1.5 \\
\hline
\end{tabular}

$\mathrm{A} 1=$ Based on 6 'centre-line' stakes for 6 years

$\mathrm{A} 2=$ Based on 11 'centre-line' stakes for 5 years

$\mathrm{A3}=$ Based on 13 'centre-line' stakes for 4 years

$\mathrm{A} 4=$ Based on 3 ' 751 ' stakes for 6 years

Units are $\mathrm{m}$ water equivalent.

and most of the semi-permanent snow patches in the area had disappeared. Many small lakes were totally dry and, from evidence of wind damage to the station and its fixtures, it was clear that the winter had been very windy. Measurements of stakes on Qamanârssûp sermia also confirmed that there had been a large amount of ablation since September 1984; two stakes had even melted out during the winter, which has never happened before.

The summer of 1985 was also exceptional. June and August were respectively the warmest of the six years of record (July was close to average). June 1985 was the wettest June on record while July 1985 was the driest July. Overall, the period June-August 1985 represented the warmest summer of the six years of record while it was somewhat drier than usual. Solar radiation conditions were close to average.

Ablation was higher than usual at almost all stakes during summer 1985, as well as during the winter. This is illustrated by Table 1 which shows four different indices of annual ablation, i.e. from 1 September to 31 August, on Qamanârssûp sermia. These indices are calculated by the method of Braithwaite (in press) from various combinations of the available data for the last six years (note they are all 'centred' on the four years 1980/81 to 1983/84). Despite some disagreements, especially for $1979 / 80$, the A1, A2 and A4 indices agree in denoting $1984 / 85$ as the year with the highest ablation.

\section{Why was ablation so high in 1985 ?}

According to Braithwaite \& Olesen (in press) the chief cause of ablation variation in Greenland is temperature variation, especially temperature above the melting point, as expressed by degree-day totals. This finding was based upon five summers of measurements at Qamanârssûp sermia, i.e. 1980-1984, as well as upon results from Johan Dahl Land. Do the latest, and exceptional, results from 1985 confirm this finding? 
Table 2. Ablation at the '751' stakes compared with degree-day totals at base camp for the six years 1979/80 to 1984/85

\begin{tabular}{lccc}
\hline Year & Season & Ablation & Degree-days \\
\hline $1979 / 80$ & Winter & $(0.84)$ & $(105)$ \\
& Summer & 3.25 & 530 \\
& Year & 4.09 & 635 \\
$1980 / 81$ & Winter & 0.92 & $(90)$ \\
& Summer & 3.77 & 527 \\
& Year & 4.69 & 617 \\
$1981 / 82$ & Winter & 0.85 & 115 \\
& Summer & 3.81 & 484 \\
& Year & 4.66 & 599 \\
$1982 / 83$ & Winter & 0.82 & 65 \\
& Summer & 2.92 & 361 \\
& Year & 3.74 & 426 \\
$1983 / 84$ & Winter & 0.45 & 73 \\
& Summer & 3.81 & 521 \\
& Year & 4.26 & 594 \\
$1984 / 85$ & Winter & 1.44 & $(160)$ \\
& Summer & 4.44 & 568 \\
& Year & 5.88 & 728 \\
Mean & Winter & 0.89 & 101 \\
& Summer & 3.67 & 499 \\
& Year & 4.56 & 600 \\
\hline
\end{tabular}

$0=$ Estimated value

Winter $=1$ September -31 May, Summer $=1$ June -31 August, Year = 1 September -31 August Units are metres water and degree-days, respectively

Ablation data from the three '751' stakes are compared with positive degree-day totals at the base camp, a few hundred metres from the stakes, in Table 2. The degree-day totals represent the sum of temperatures above the melting point and are mainly derived from the manned and automatic climate stations at base camp although extrapolations from Godthåb have been used for the months with missing record. The results confirm that the 1984/85 winter had both the highest ablation, i.e. $1.44 \mathrm{~m}$ water, and highest degree-day total of the six winters. Similarly, the 1984/85 summer had the highest ablation, i.e. $4.44 \mathrm{~m}$ water, and highest degree-day total of the six summers.

The parameter linking ablation to degree-day total is the degree-day factor. It is not necessarily constant and will cause ablation variations in addition to those caused by temperature, or degree-day, variations. The mean ablation for the first five years in Table 2 was $4.29 \mathrm{~m}$ water. If this is regarded as 'normal' for purposes of the present discussion, the ablation in 1984/85 was $1.59 \mathrm{~m}$ above normal. The degree-day factor for $1984 / 85$ was $8.1 \mathrm{~mm}$ $\mathrm{d}^{-1} \mathrm{deg}^{-1}$ compared to the corresponding normal value of $7.4 \mathrm{~mm} \mathrm{~d}^{-1} \mathrm{deg}^{-1}$. The $1.59 \mathrm{~m}$ of excess ablation in 1984/85 can then be split up into $1.05 \mathrm{~m}$ due to the high temperature, i.e. degree-day total, and $0.54 \mathrm{~m}$ due to the high degree-day factor. The reasons for variations in degree-day factor are still not understood although Braithwaite \& Olesen (in press) discuss some possibilities. 


\section{Implications}

Before the 1985 field season it was suggested that conditions had become well enough understood that a simpler, and cheaper, field programme could be introduced. As a first step in this process, the first field team of 1985 was cut from three men to two. This seemed a reasonable economy measure as previous experience had indicated that there was insufficient work for three at the start of the season. However, the high ablation during the winter meant that the team had to immediately re-drill many stakes, which is more comfortably a threeman job. The high ablation during the summer also meant that extra re-drilling had to be done at the end of the summer, following the usual re-drilling carried out in July. This example shows that proposals for changing the field programme must be tested against extreme conditions.

After the first five years of investigations at Qamanârssûp sermia the degree-day factor would have been estimated to be $7.4 \mathrm{~mm} \mathrm{~d}^{-1} \mathrm{deg}^{-1}$ while a value of $7.6 \mathrm{~mm} \mathrm{~d}^{-1} \mathrm{deg}^{-1}$ is obtained after six years of work. By comparison, a degree-day factor of $6.3 \mathrm{~mm} \mathrm{~d}^{-1} \mathrm{deg}^{-1}$ was assumed by Braithwaite (1980) before any measurements were made at Qamanârssûp sermia. This shows that the field programme has been useful in showing that the degree-factor is larger than previously believed. On the other hand, although exceptional, the 1985 results have not changed the 1980-1984 picture very much.

In the broader context of Greenland hydropower, the exceptional conditions of 1984/85 illustrate the fact that high ablation often occurs together with low precipitation. This has the effect of smoothing year-to-year variations in runoff from glacierized basins compared with purely precipitation basins (Braithwaite, 1985c). This is of great practical benefit.

\section{References}

Braithwaite, R. J. 1980: Regional modelling of ablation in West Greenland. Rapp. Grønlands geol. Unders. $98,20 \mathrm{pp}$.

Braithwaite, R. J. 1985a: Glaciological investigations at Qamanârssûp sermia, West Greenland, 19831984. Grønlands geol. Unders. Gletscher-hydrol. Meddr 85/3, 26 pp.

Braithwaite, R. J. 1985b: Glacier-climate investigations in 1984 at Qamanârssûp sermia, West Greenland. Rapp. Grønlands geol. Unders. 125, 108-112.

Braithwaite, R. J. 1985c: Relations between annual runoff and climate, Johan Dahl Land, South Greenland. Grønlands geol. Unders. Gletscher-hydrol. Meddr 85/2, 25 pp.

Braithwaite, R. J. in press: Assessment of mass-balance variations within a sparse stake network, Qamanârssûp sermia, West Greenland. $J$. Glaciol.

Braithwaite, R. J. \& Olesen, O. B. in press: Ice ablation in West Greenland in relation to air temperature and global radiation. Z. Gletscherk. Glazialgeol. 